\title{
The Promotion of Russian Music Culture on Harbin Music Education in the 20th Century*
}

\author{
Qi Wang \\ Heihe University \\ Heihe, China
}

\begin{abstract}
Russia has rich historical and cultural heritage and unique ethnic characteristics, especially in the field of music. Due to the geographical location, Russia and China have very close links in politics, economy, culture and art, and Russia has an obvious influence especially on China's culture and art. Harbin, a city in the northeast of China, has a long history of receiving immigrants from Russia. Naturally, Harbin is influenced by the 20th century Russian music culture, inevitably bearing the imprint of the Russian nation in its music development course, which has had a positive impact on the development of Harbin's own music education.
\end{abstract}

Keywords—Russia; music culture; Harbin; education; role

\section{INTRODUCTION}

Russian music has a long history of development. Russia is a country that attaches great importance to music and art, and its national music is well-known in the world. After the victory of the Russian October Revolution in the 20th century, the development of Russian music and art has entered a new stage, showing new artistic features. And Russia has constantly cultivated many internationally renowned musicians such as Tchaikovsky, Glinka, Rachmaninoff and so on. Harbin, which is in Heilongjiang Province, borders Russia with the Heilongjiang River and Wusuli River. Over the years, Harbin has received Russian immigrants. The influx of Russians has injected fresh blood of Western music into the music of Harbin. They established clubs, symphony orchestras as well as music schools in Harbin. It can be said that the development of modern music in Harbin and even China is inevitably imprinted with Russian music culture.

\section{ANALYSIS OF THE ARTISTIC FEATURES OF RUSSIAN MUSIC IN THE 20TH CENTURY}

Russia's national character is passionate and unrestrained, and the nation especially loves music art. After Harbin was identified as the central hub of the Middle East Railway in 1898, a large number of Russians, together with their symphonies, operas, choruses, and other musical cultures with strong national characteristics, were stationed in Harbin. In the 20th century, Russian music entered a new stage with

*Fund Project: Heilongjiang Philosophy and Social Science Research Planning Project "Study on the Multi-dimensional Influence of Russian Music Culture in the 20th Century on Harbin Urban Music" (No. 18YSE620). the victory of political struggle and became an important manifestation of multi-ethnic Soviet music. Russian music mainly has three unique artistic features: lyricism, joy and melancholy.

\section{A. Strong Lyric Color}

After the victory of the Russian October Revolution in the 20th century, Russia's political form and social form have undergone tremendous changes. These changes were also reflected in the Russian music, and the Russian revolutionary songs have been widely created and disseminated. With the political and social changes, the most obvious new feature of Russian classical music in the 20th century was that the lyricism had been greatly enhanced. In the early 20 th century, Russian classical music had a strong political significance, opposed to the tsarist autocratic rule. Russian people used the touching artistic power to achieve their political goals. However, with the weakening of political mission, the lyricism of Russian music has not decreased, but increased. The Russians often used long and deep tunes and melodies to tell stories. The music required a wide breath and had exquisite structures. Vivid interest and charm was reflected in the simple but elegant music, and rich emotions were expressed in the melodious music. The Russian music has had a subtle effect on people's spirits through its unique artistic appeal.

\section{B. Strong National Character}

The Russian people are resolute, strong and unyielding, which is the national character of Russia. They are very patriotic, and their works "Mitternacht in Moskau" and "Swan Lake" are well known. The Russians have an optimistic nature. This nature is also reflected in the form and style of Russian music. The passionate national nature and the national spirit to strive for the best all make Russian national music reflect its unique national charm. The "Ruslan and Lyudmila Overture" is a piece of typical 20th century Russian classical music. It uses a vivid musical language to connect the plots, supplemented by the sonata. The tone of the whole song is bright and cheerful, full of joy and festive color. It fully demonstrates the optimism of the Russians and at the same time has some characteristics of the folk songs, reflecting the folk culture and national spirit of Russia in the 20 th century. 


\section{Strong Melancholy Emotion}

Due to Russia's historical conditions, the music of the Russian nation has a strong tragic color. Russia is a tragic country, which makes tragedy become the main feature of Russian national music. Looking back on the past, the seriousness of the Russian national history runs through the soul of the entire national music. Although this deep emotion in the music will make people feel melancholy when listening to the music, it is hard for people to refuse the music. Tchaikovsky' s works have undoubtedly reflected this feature. And the works of contemporary famous musicians such as Glinka have played an important role in promoting the development of Russia's national music.

\section{THE IMPRINT OF RUSSIAN MUSIC IN THE DEVELOPMENT OF MUSIC EDUCATION IN HARBIN}

\section{A. Family Music}

The Russian nation itself is a nation that is good at singing and dancing, and the nation owns rich musical connotation and music culture. This culture in great degree originated from the family music education. In various families in Russia, parents pay great attention to the musical literacy of future generations. Therefore, in daily life, they attach great importance to the musical training of the next generation. Most Russian families would employ music teachers to teach their children to play piano and make vocal performance, letting the children receive music education since their childhood. At the same time, in order to cultivate children's musical literacy, they often take their children to attend musical concerts, ballet performances, and other musical activities. The influence of Russian families' cultivation of children's musical literacy on Harbin was revealed after a long period of time. With the passage of time, in the 1920s, most middle-class families in Harbin began to imitate the music education method of Russian families, and specially hired Russian music teachers to teach their children to cultivate children's music connotation and music literacy, which is crucial for the development of Harbin music culture and has played a role in promoting the development of Chinese music.

\section{B. Ordinary Music}

In Heilongjiang, the music education in most ordinary schools is influenced by local culture to a certain extent, and is also influenced by the culture of Japan and Russia. These three kinds of music cultures have met in Harbin and interacted with each other to form the Harbin music culture seen by us today. Among these three cultures, Russian culture still plays a dominant role, which has greatly promoted the development of Harbin music. This promoting action is specifically embodied in the following aspects:

1) The deepening of Russian language teaching: In ordinary schools in Harbin, the learning of Russian language is extremely common. In the first half of the 20th century, influenced by Tsarist Russia and later by the Soviet Union, Russian language classes were very common in Harbin, and the atmosphere in Harbin to learn Russian language was very strong. This atmosphere was not formed overnight. It was a result of Harbin's local culture's being influenced by Russian culture in nearly a century. In the education of Russian language in Harbin, in order to allow students to fully grasp Russian pronunciation skills, as well as sentences and grammars, etc., teachers would quote some Russian songs in their teaching, so that students could learn Russian language unconsciously in the process of singing Russian songs. As a result, a phenomenon had emerged that Russian songs had been widely sung on campus, and the songs were then spread to the society, which has a positive effect on the development of Harbin music culture.

2) The deepening of Russian instrumental music teaching: As early as in the 1920s, a large number of Russians and Belarusians entered Chinese schools. While they were receiving Chinese education, they also introduced Western culture to China. This introduction of culture was mainly embodied in the musical instruments. As mentioned above, Russian families attach great importance to the training of children's musical literacy. Parents will let the children learn musical instruments since their childhoods. Therefore, at the same time a large number of Russian children entered Chinese schools, they also brought Western instruments that were not familiar to Chinese children into the schools. On the one hand, the emergence of this phenomenon has promoted the teaching of music instruments in Harbin. On the other hand, the Russian accordion also became very popular on campus at that time, which promoted Chinese children's independent learning of musical instruments.

3) The deepening of Russian music teaching: At the beginning of the 20th century, under the influence of Russian music, the music culture of Harbin continued to develop. And in the 1950s, Russian music education was completely introduced to Harbin. Russian music education mainly contains two parts. The first part is the teaching of basic knowledge, such as the intervals, scales and chords included in the music theories, while the other part is the teaching of professional skills, such as piano performance, vocal performance, etc. As for the educational system, Heilongjiang comprehensively drew on the mode of Russian music education, and developed a music education mode that conformed to the actual situation of Heilongjiang on the basis of its original mode, and finally established a music training mode combining professional and occupational characteristics. Although the Russian music teaching method was actively introduced in the music education of Harbin, the local music education atmosphere in Harbin was still slightly weak, and Harbin's local music education was not so mature and effective as Russian music education. However, it couldn't be denied that Russia's promotion of Harbin's music culture has made Harbin's music culture education develop a lot. 


\section{Professional Music}

In February 1917, the October Revolution broke out and a large number of Russians immigrated to Harbin. Among them, there were some world-famous musicians, including the famous singer Brott Volskaya, the famous pianist Gersch Gorina and so on. These musicians have achieved very impressive attainment in both instrumental and vocal performances, and their professional performances have had a great influence on the development of Harbin music at that time. They not only paid attention to the expression of the music, but also attached great importance to the singing skills. They introduced advanced music skills into Harbin, which had a positive effect on the development of Harbin music, and at the same time promoted the development of technologies and skills of Harbin music. The arrival of these musicians not only affected the development of music skills, but also affected music education in Harbin. The musicians attached great importance to music education and established systematic music education. Due to this, more than 30 professional music schools were established in Harbin, the most famous among which was Harbin No.1 Higher Music School, and it is also the first modern music school in China. It took Russian royal music education model as the main teaching model. In July 1925, Harbin Glazunov Higher Music School was established, and the school was located in Tongjiang Street, Harbin. The buildings of the school were designed by the famous Russian designer Joseph Yuriyevich Levigin. This school made some innovations on the educational model. Courses in music history and art development history were added on the basis of the original education mode. In October 1927, Russians and their church established a music training class in Harbin, of which the main training content was the music and Western religions. In 1929, the Harbin Music School was established. After that, the music training class merged with the No.1 higher music school, which happened in 1948. The above four schools were all founded by Russians. This not only promoted the development of Harbin music to a certain extent, but also played a positive role in the development of music in China. The establishment of the schools have made the modern music skills and musical concepts fully introduced into the Harbin music culture, which had a positive impact on the development of music education in Harbin.

\section{THE INFLUENCE OF RUSSIAN MUSIC CULTURE ON HARBIN MUSIC EDUCATION IN THE 20TH CENTURY}

\section{A. The Influence of Russian Music Culture on the General Music Education in Harbin in the 20th Century}

General music education, as the name implies, refers to the art education for young children through schools' music lessons, and can also be regarded as national music education. Before the "May 4th Movement", music and other art disciplines have always been paid little attention to in Harbin and even the national school education. With China's continuous learning of advanced education concepts in Russia, Japan and other countries, China's music education has entered a new stage, and the main performances are as follows: 1. Under the influence of the school songs and the constant immigration of Russians, there appeared the first batch of music and art education talents in China, which has provided teachers for the development and construction of general music education in Harbin and other regions. 2. Under the influence of a large number of Russian musicians and music educators, the government departments of Heilongjiang and all walks of life have paid more attention to music education, and gradually improved the proportion of music lessons in school music education. 3. The basic knowledge and educational concepts of some western music theories in Europe have been introduced into Harbin through Russian immigrants, such as staves, musical instrument playing methods, and harmonics. These have made a profound and positive impact on the school music enlightenment education in Harbin.

\section{B. The Influence of Russian Music Culture on the Social Music Education in Harbin in the 20th Century}

Social music education has similar functions to the general music education in schools in improving the music literacy of people. The two complement each other. With the rise of the New Culture Movement and the increasing openness of the society, the early social music education in Harbin was slowly developed. At the same time, under the influence of the Russian immigrants, many music associations quietly rose in Harbin. They held concerts, held chorus competitions, issued publications, studied the relationship between Chinese and Western music, and discussed issues related to China's new music culture, making the people in Harbin have a deeper understanding of music and generating a certain influence on the music education circle in Harbin at that time.

\section{The Influence of Russian Music Culture on Harbin Normal Music Education in the 20th Century}

At the beginning of the 20th century, in order to provide enough music teachers for primary and secondary schools, Harbin began to pay more attention to the cultivation of music teachers. Along with the founding of the People's Republic of China and the deepening of Sino-Russian diplomatic relation, various advanced Russian cultural thoughts flocked to China. Many music intellectuals studying in Russia returned to Harbin to teach in schools. In 1951, under the call of the Ministry of Education, Harbin, Heilongjiang established the first normal school "Harbin Teachers College" in Heilongjiang, and a large number of Russian educators and scholars were introduced to this school to give lectures. The school attached great importance to the cultivation of music teachers in music education. It cultivated a group of influential music teachers in the early music education circles of Heilongjiang, changed the situation that Chinese schools had to rely on foreign music teachers to teach before, and laid a good foundation and accumulated much school-running experience for the development of music teacher cultivation in Harbin and even other northeastern provinces.

\section{CONCLUSION}

In the 20th century, due to historical reasons, Chinese people and foreign immigrants lived together in Harbin. In 
the process of coexistence of different cultures, there were unavoidable estrangements and collisions. But ultimately, the Chinese and immigrants broke down barriers between their cultures, diluted the prejudice, and enhanced understanding about each other, jointly promoting the formation and development of Harbin multiculturalism. Russian music culture greatly promoted the development of music education in Harbin. Russian music culture not only promoted the development of Harbin music, but also promoted China to accept Western music cultures and develop its own music culture.

\section{REFERENCES}

[1] Wang Qi, Xu Wei. The Influence of Russian National Music on the Development of Heilongjiang Music in the Twentieth Century[J]. Northern Music, 2017, 37(13): p254. (in Chinese)

[2] Liu Yuan. A preliminary study on the Harbin music groups established under the influence of Russian music culture in the early 20th century[J]. Northern Music, 2014, (16): p6. (in Chinese)

[3] Wang Qi. The influence of Russian national music in the 20th century on the development of Heilongjiang music[J]. Art and Literature for the Masses, 2017, (7): pp.150-151. (in Chinese)

[4] Wen Huiming, He Yi. Enlightenment from String Music Teaching in Harbin Overseas Russian Music Schools[J]. Journal of Engineering of Heilongjiang University, 2017, 31(2): pp.60-62. (in Chinese)

[5] Wang Qi. The Enlightenment from Russian Singing Art on Vocal Music Teaching in Chinese Universities[J]. Northern Music, 2016, 36(4): p188. (in Chinese)

[6] Hu Xueli. The Architecture of Soviet Music Aesthetics in China The Influence of Soviet Music in the First Half of the 20th Century on Chinese Music Creation[J]. Charming China, 2014, (18): p113. (in Chinese)

[7] Wang Qi. The promoting effect of Russian music culture in the 20th century on the development of Heilongjiang music [J]. Music Space, 2016. (in Chinese)

[8] Li Xiumin. The Origin of Harbin Regional Culture with Russian Characteristics[J]. Heilongjiang Social Sciences, 2005, (04). (in Chinese) 